inquiry into stillbirths and deaths in infancy, and others who provided advice and information to the study.

Contributors: Both authors designed the study, analysed the data, and wrote the paper. PAT collected the data and REG is the guarantor.

Funding: Department of Health.

Competing interests: None declared.

1 Odent M. Birth underwater. Lancet 1983;ii:1476-7

2 Church L. Waterbirth: one birthing center's observations. J Nurse Midwifery 1989;34:165-70.

3 Alderdice F, Renfrew M, Marchant S, Ashurst H, Hughes P, Berridge G, et al. Labour and birth in water in England and Wales. BMJ 1995;310:837.

4 Cammu H, Clasen K, Van Wettere L, Derde M-P. "To bathe or not to bathe" during the first stage of labour. Acta Obstet Gynaecol Scand 1994;73:468-72

5 Page L, Kitzinger S. A midwifery perspective on the use of water in labour and birth. Matern Child Health 1995;Jan:22-6.

6 Schorn MN, McAllister JL, Blanco JD. Water immersion and the effect on labor. J Nurse Midwifery 1993;38:336-42.

7 Rush J, Burlock S, Lambert K, Loosley-Millman M, Hutchison B, Enkin $M$. The effects of whirlpools baths in labor: a randomized, controlled trial. Birth 1996;23:136-43.

8 Nikodem VC. Immersion in water during pregnancy, labour and birth In: Cochrane Collaboration. Cochrane Library. Issue 3. Oxford: Update Software, 1998.

9 Levene ML, Kornberg J, Williams THC. The incidence and severity of post-asphyxial encephalopathy in full term infants. Early Hum Dev 1985;11:21-6.

10 Rosevear SK, Marlow N, Stirrat GM. Birthing pools and the fetus. Lancet 1993;342:1048-9.

11 Rawal J, Shah A, Stirk F, Mehtar S. Water birth and infection in babies. BMJ 1994;309:511.
12 Parker PC, Boles RG. Pseudomonas otitis media and bacteremia following a water birth. Pediatrics 1997;99:653.

13 Roome APCH, Spencer RC. Birthing pools and infection control. Lancet 1996;348:274.

14 Rosser J. Is water birth safe? The facts behind the controversy. MIDIRS Midwifery Digest 1994:4:4-6.

15 Hall S, Nicoll A. The British Paediatric Surveillance Unit-a pioneering method for investigating the less common disorders of childhood. Report of a seminar held in June 1995. Child Care Health Dev 1997;24:129-43.

16 Alderdice F, Renfrew M, Marchant M, Ashurst H, Hughes P, Berridge G, et al. Labour and delivery in water in England and Wales: survey report. BrJ Midwifery 1995;3:375-82.

17 Arya R, Pethen T, Johanson R, Spencer S. Outcome in low risk pregnancies. Arch Dis Child 1996;75:F97-102.

18 Middle C, MacFarlane A. Labour and delivery of "normal" primiparous women: analysis of routinely collected data. $\mathrm{Br} J$ Obstet Gynaecol 1995; 102:970-7.

19 Barry CN. Could saline in the pool reduce the potential hazards? BMJ 1995;310:1602.

20 Johnson P. Birth under water-to breathe or not to breathe. Br J Obstet Gynaecol 1996;103:202-8.

21 Hull J, Dodd KL. Falling incidence of hypoxic-ischaemic encephalopathy in term infants. Br J Obstet Gynaecol 1992;99:386-91.

22 Northern Region Perinatal Mortality Survey Coordinating Group Collaborative survey of perinatal loss in planned and unplanned home births. BMJ 1996;313:1306-9.

23 Ford C, Iliffe S, Franklin O. Outcome of planned home births in an inner city practice. BMJ 1991;303:1517-9.

24 Cleary R, Beard R, Chapple J, Coles J, Griffin M, Joffe M, et al. The standard primipara as a basis for inter-unit comparisons of maternity care. $\mathrm{Br}$ J Obstet Gynaecol 1996;103: 223-9.

(Accepted 25 May 1999)

\title{
Polymorphism in high density lipoprotein paraoxonase gene and risk of acute myocardial infarction in men: prospective nested case-control study
}

\author{
Jukka T Salonen, Riikka Malin, Tomi-Pekka Tuomainen, Kristiina Nyyssönen, Timo A Lakka, \\ Terho Lehtimäki
}

Increased lipid peroxidation is associated with accelerated progression of atherosclerosis. ${ }^{1}$ Paraoxonase (paraoxonase/arylesterase) is an antioxidative enzyme in high density lipoproteins, which protect against coronary disease. ${ }^{23}$ It eliminates organophosphorus pesticides but also the products of lipid peroxidation. ${ }^{24}$ The mutation at position 54 of the paraoxonase gene in which methionine is substituted by leucine (Met54Leu) has an effect on paraoxonase, increasing its activity; people who have the methionine allele show decreased paraoxonase activity. ${ }^{4}$ Only a few studies have looked at the association of the Met54Leu polymorphism with coronary disease, ${ }^{25}$ and the findings are inconclusive. Thus we carried out a prospective study of the role of this polymorphism on the risk of acute myocardial infarction in healthy men from eastern Finland.

\section{Participants, methods, and results}

Our prospective nested case-control study was carried out among participants in the Kuopio ischaemic heart disease risk factor study. We examined 2682 (83\%) of 3235 invited men aged 42, 48, 54, or 60 during 1984-9. Blood samples were collected and risk factors assessed at baseline. A DNA sample was available for this study for 1137 men who were free of coronary disease. We registered and verified all myocardial infarctions- definite or possible-between the baseline examinations and the end of 1995 . $^{3}$ The mean follow up time was 8.5 years, and in patients who had had multiple infarctions we considered only the first.

The cases were all 55 men (among the 1137) who had had an infarction by 1995 . The controls were drawn from the remaining members of the same cohort. Two controls for each case (110 men) were matched according to the most important non-genetic risk factors for myocardial infarction in the Kuopio ischaemic heart disease risk factor study cohort. For the 165 men, paraoxonase genotypes were determined by using a polymerase chain reaction method with Hsp92II enzyme digestion. ${ }^{4}$ We used logistic regression modelling to analyse the association of paraoxonase genotypes with the risk of myocardial infarction.

Of the cases, 13 (24\%) were homozygous for the M allele (MM), 22 (40\%) were heterozygous (ML), and 20 $(36 \%)$ did not carry it (LL). Of the controls, $11(10 \%)$ had an MM genotype, 54 (49\%) an ML, and 45 (41\%) an LL. In a logistic model adjusted for the other strongest risk factors the odds ratio for the MM genotype was 3.38 (95\% confidence interval 1.17 to 9.83 ; $\mathrm{P}=0.025$ ) (table, model 1). An additional adjustment for serum concentration of the second subfraction of high density lipoprotein cholesterol $\left(\mathrm{HDL}_{2}\right)$ attenuated
Research Institute of Public Health and Department of Public Health and General Practice, University of Kuopio, PO Box 1627,70211 Kuopio, Kuopio, Finland

Jukka T Salonen professor of epidemiology Tomi-Pekka Tuomainen research fellow Kristiina Nyyssönen clinical biochemist Timo A Lakka senior research fellow continued over

BMJ 1999;319:487-9 
Department of Clinical Chemistry, Tampere University Hospital, and Research

Laboratory for Atherosclerosis Genetics, University of Tampere Medical School, Tampere, Finland

Riikka Malin associate research fellow

Terho Lehtimäki senior research fellow

Correspondence to: Professor Salonen jukka.salonen@ uku.fi

Strongest risk factors for acute myocardial infarction in two multivariate logistic models

\begin{tabular}{|c|c|c|c|c|c|c|}
\hline \multirow[b]{2}{*}{ Risk factor } & \multicolumn{3}{|c|}{ Model 1} & \multicolumn{3}{|c|}{ Model 2} \\
\hline & Odds ratio & $95 \% \mathrm{Cl}$ & $P$ value & Odds ratio & $95 \% \mathrm{Cl}$ & $P$ value \\
\hline Paraoxonase genotype MM ( $v$ LL) & 3.38 & 1.17 to 9.83 & 0.025 & 3.07 & 1.03 to 9.17 & 0.044 \\
\hline Paraoxonase genotype ML $(v \mathrm{LL})$ & 1.10 & 0.49 to 2.45 & 0.820 & 1.00 & 0.44 to 2.25 & 0.998 \\
\hline Family history of coronary heart disease (yes $v$ no) & 2.48 & 1.17 to 5.27 & 0.018 & 2.91 & 1.33 to 6.36 & 0.008 \\
\hline Packed cell volume & 1.21 & 1.04 to 1.40 & 0.015 & 1.20 & 1.03 to 1.40 & 0.021 \\
\hline Serum apolipoprotein B (g/l) & 5.95 & 1.12 to 31.5 & 0.036 & 3.21 & 0.56 to 18.4 & 0.189 \\
\hline Plasma fibrinogen $(\mathrm{g} / \mathrm{l})$ & 1.70 & 1.07 to 2.71 & 0.071 & 1.66 & 0.92 to 2.98 & 0.091 \\
\hline Lipid-standardised vitamin E & 0.18 & 0.02 to 1.57 & 0.122 & 0.14 & 0.02 to 1.29 & 0.083 \\
\hline Serum $\mathrm{HDL}_{2}$ cholesterol $(\mathrm{mmol} / \mathrm{l})$ & & & & 0.12 & 0.02 to 0.71 & 0.020 \\
\hline Entire model & & & 0.0002 & & & $<0.0001$ \\
\hline
\end{tabular}

$\mathrm{HDL}_{2}=$ second subfraction of high density lipoprotein.

this odds ratio to 3.07 (1.03 to $9.17 ; \mathrm{P}=0.044$; table, model 2).The odds ratio for the MM genotype remained unchanged after any other risk factor was forced into the model. The odds ratio was significantly $(\mathrm{P}<0.05)$ higher among the 59 smokers $(40.8$ (2.65 to $629.2) ; \mathrm{P}=0.008)$ than the 106 non-smokers (1.55 (0.45 to 5.32); $\mathrm{P}=0.488)$.

\section{Comment}

In this prospective population based study, men who were MM homozygous for the Met54Leu polymorphism of paraoxonase had over a threefold risk of a first myocardial infarction compared with men who did not carry the $\mathrm{M}$ allele (LL). People with the $\mathrm{M}$ allele have reduced plasma concentrations and activities of paraoxonase. ${ }^{2}$

Men with the genotype conferring low activity of paraoxonase (MM) had about three times the risk of myocardial infarction than had men with the genotype conferring high activity (LL). The genotype at increased risk is common: a tenth of our healthy controls had it. According to our data, close to a fifth of all infarctions in our healthy cohort of middle aged men would be attributable to this single genetic polymorphism through either direct causation or linkage to other genes. Our findings suggest that paraoxonase has a protective role against coronary disease.
We thank Terhi Nissinen for DNA extractions; Kari Seppänen for lipoprotein analyses; and Kimmo Ronkainen for data management and matching.

Contributors: JTS is the guarantor of the study. JTS initiated and organised the Kuopio ischaemic heart disease risk factor study; JTS, TL, and T-PT planned the study concerning paraoxonase genotypes; RM and TL did the genotypings; $\mathrm{KN}$ is responsible for the chemical measurements; TAL classified the heart attacks; and JTS analysed the data. All authors participated in writing the manuscript.

Funding: The Kuopio ischaemic heart disease risk factor study was supported by grant HL44199 from the National Heart, Lung, and Blood Institute to George A Kaplan and by grants from the Academy of Finland (to JTS), the Finnish Ministry of Education (JTS, TAL), the Emil Aaltonen Foundation (TL), and the Finnish Foundation of Cardiovascular Research (RM, TL).

Competing interests: None declared.

Salonen JT, Ylä-Herttuala S, Yamamoto R, Butler S, Korpela H, Salonen $\mathrm{R}$, et al. Autoantibody against oxidised LDL and progression of carotid atherosclerosis. Lancet 1992;339:883-7.

2 Garin MC, James RW, Dussoix P, Blanche H, Passa P, Froguel P, et al. Paraoxonase polymorphism Met-Leu54 is associated with modified serum concentrations of the enzyme. A possible link between the paraoxonase gene and increased risk of cardiovascular disease in diabetes. J Clin Invest 1997;99:62-6.

3 Salonen JT, Salonen R, Seppänen K, Rauramaa R, Tuomilehto J. High density lipoprotein, $\mathrm{HDL}_{2}$ and $\mathrm{HDL}_{3}$ subfractions and the risk of acute myocardial infarction: a prospective population study in eastern Finnish men. Circulation 1991;84:129-39.

4 Humbert R, Adler DA, Disteche CM, Hassett C, Omiecinski CJ, Furlong $\mathrm{CE}$. The molecular basis of the human serum paraoxonase activity polymorphism. Nature Genet 1993;3:73-6.

5 Sanghera DK, Saha N, Kamboh MI. The codon 55 polymorphism in the paraoxonase 1 gene is not associated with the risk of coronary heart disease in Asian Indians and Chinese. Atherosclerosis 1998;136:217-23. (Accepted 26 November 1998)

\section{Commentary: Causality-the Achilles' heel of observational studies}

Marcus D Flather

Clinical Trials and Evaluation Unit, Royal Brompton Hospital, London SW3 6NP Marcus D Flather director m.flather@rbh. nthames.nhs.uk
Salonen et al use a nested case-control design to correlate risk of myocardial infarction for different paraoxonase genotypes. The method identified incident cases and matched them to controls in a ratio of 1 to 2 . This approach uses a subset of subjects from a larger cohort to address a particular hypothesis.

Case-control studies are one of the weakest methods to infer a causal association between a risk factor and a disease. On the other hand, they are simple to perform and useful for generating hypotheses. Problems of bias arise because of difficulty in matching cases to controls and the presence of multiple known and unknown confounding variables. Apparently significant results can arise by chance because of multiple testing, and some statistical approaches can be tipped in favour of significance in borderline cases.
In this study associations between genotype and risk of myocardial infarction were comparatively weak (lower limit of 95\% confidence interval 1.17 $(\mathrm{P}=0.025)$ in the unadjusted analysis and 1.03 $(\mathrm{P}=0.044)$ in the adjusted model $)$, which does not give great confidence in the causality of the findings. The main problem is that the number of subjects in the analysis is small. The hypothesis is intriguing and deserves a fair appraisal.

The correct next step would be to replicate these findings in a similar cohort study that had obtained DNA samples. Collaboration among groups with well documented cohorts would provide a major advance in the assessment of promising new markers of risk in both epidemiological and interventional studies after the publication of the main results of individual studies. 
This approach would help to reinforce or refute observations of borderline significance.

The importance of an association between a particular genotype and risk of disease allows people at high risk to be counselled appropriately and modifiable risk factors to be treated more aggressively. In certain circumstances, correcting a protein deficiency with supplements may be helpful. Genetic manipulation, although intuitively attractive, is associated with practical, technical, and ethical problems but may be a treatment of the future. Most cases of myocardial infarction are unlikely to be due to a single gene defect. Nevertheless, the report by Salonen et al helps to increase understanding of genotype and disease and to identify promising areas of research.

\section{Commentary: How high density lipoprotein protects against heart disease}

High density lipoprotein protects against cardiovascular disease. Protection is conferred in at least two ways. The first way is by transporting cholesterol back from organs such as arteries to the liver, thus protecting the arteries from further atheromatous plaque formation. The second way is by acting as an antioxidant. ${ }^{1}$ Lipid peroxidation encourages atheroma formation, so that anything which limits lipid peroxidation should reduce the risk of cardiovascular events. The component of high density lipoprotein that is most likely to provide antioxidant activity is paraoxonase.

In this study Salonen et al examined the paraoxonase gene of 165 men. One genetic mutation appeared quite commonly. In this mutation methionine is substituted by leucine at one particular position in the enzyme's protein structure, increasing the enzyme's antioxidant activity. Men who did not carry this mutation (that is, those who were homozygous for the $\mathrm{M}$ allele) had three times the risk of myocardial infarction of those who did.

These observations suggest that paraoxonase is more active when the mutation is present and less active when it is not and that paroxonase might be protective against cardiovascular disease.

\section{Abi Berger science correspondent, BMJ}

1 Navab M, Berliner JA, Watson AD, Hama SY, Territo MC, Lusis AJ, et al The yin and yang of oxidation in the development of the fatty streak. A review based on the 1994 George Lyman Dyff memorial lecture. Arterioscler Thromb Vasc Biol 1996;16:831-42.

\section{A memorable patient The screaming man}

I had to meet two social workers and a GP on a housing estate in London. When I got there the patient was out but two of his neighbours told us that he'd gone for a walk. So we waited to see if he'd return. While we did so, it was difficult to ignore the screaming that emanated from higher up in the flats, on the third or fourth floor. The sound was guttural, like an animal: a growling, bellowing roar.

I kept thinking that the screaming might be coming from our man, but the neighbours said not. It had been going on for three or four days and nights, continuously. They'd been going to call the police, but no one had. While we waited the screaming continued. More neighbours gathered, interested to see what was happening. Some said, "Something must be done" (about the screaming), while others were more concerned about our motives. "What did you want?"” What are you doing here?"

It transpired that a young man-on medication-lived alone on the third floor. One of the social workers had a mobile phone and called the police. Perhaps they'd break the door down. The ambulance, called for the original patient-the one who'd gone for a walk-had to leave because of an alert.

The police came, and we approached the flat. The growling and screaming continued. We knocked on the door, shuffling for standing room on the crowded, narrow balcony. The screaming stopped. A man opened the door. He was young, thin, and dishevelled, with beads of sweat on his forehead, and matted hair. He was surprisingly softly spoken. He let us in. There was no carpet and very little furniture. The bare wooden floorboards were covered in patches of water and the sites of small fires, lit with paper and matches but now extinguished. In the main room was a single bed, heaped with dirty clothes. There was an overcrowded dresser, but no place to sit.
We stood in the centre of the room and the police maintained a respectful distance. A second ambulance had arrived and was parking outside. The man kept turning his attention to the flickering blue light that strobed the window. If a place can reflect a psyche then this man's room did: the blue light, beaming across his sparse and scattered objects; the disorder of his internal world. He stared apprehensively; he knew something was going on. He was edgy and acutely paranoid.

Why was he screaming? He did it to stop the thought interference. It was the only way. Thoughts came into his head, all the time, from outside. The screaming seemed to clear his mind, helped him regain control, but then he'd need to scream again. He'd stopped his medication. Would he come into hospital? Yes.

The crowd dispersed as the ambulance drove away. A common event in that community. Twice more that week I would stand in cramped living rooms, surrounded by the heaped possessions of psychotic people, sitting in fear in the dark. Solitary people, in small rooms, their curtains drawn for fear of their persecutors: the delusional variety, who interfere with their thoughts, and the physical kind, who regard them as strange, who hear them scream, yet do nothing. That community, where some may cry for help, while others must scream out loud.

Sean A Spence, locum consultant psychiatrist, London

We welcome articles up to 600 words on topics such as A memorable patient, A paper that changed my practice, My most unfortunate mistake, or any other piece conveying instruction, pathos, or humour. If possible the article should be supplied on a disk. Permission is needed from the patient or a relative if an identifiable patient is referred to. 